\title{
A review on analysis of ferrocement panels.
}

\section{Una revisión sobre el análisis de paneles de ferrocemento.}

\author{
Nabeela M.M ${ }^{1}$, Parvathy Krishnan ${ }^{1}$, Prabha $C^{2}$ \\ ${ }^{1}$ PG Student, ${ }^{2}$ Assistant Professor \\ Department of Civil Engineering \\ Mar Athanasius College of Engineering, Kothamangalam (Kerala), India
}

Corresponding author mail id: nabeelaajmy@gmail.com, parvathykrishnan101@gmail.com

\begin{abstract}
Ferrocement is a highly versatile form of reinforced concrete made up of wire mesh, sand, water, and cement, which possesses unique qualities of strength and serviceability. It displays a series of advantages compared to reinforced concrete. Now a days ferrocement is widely used in engineering application due to high performance regards to the resistance to extension, resistance to impact, ductility. Numerous studies were conducted to understand the behaviour of ferrocement panels. This paper presents the review of studies conducted about the behaviour of ferrocement panel under static, dynamic, cyclic loading. Keywords- Ferrocement, cyclic loading, flexural behaviour, precast ferrocement wall, dynamic analysis, static analysis
\end{abstract}

\section{RESUMEN}

El ferrocemento es una forma muy versátil de hormigón armado compuesto de malla de alambre, arena, agua y cemento, que posee cualidades únicas de resistencia y facilidad de servicio. Presenta una serie de ventajas frente al hormigón armado. Hoy en día, el ferrocemento se usa ampliamente en aplicaciones de ingeniería debido a su alto rendimiento en cuanto a resistencia a la extensión, resistencia al impacto y ductilidad. Se realizaron numerosos estudios para comprender el comportamiento de los paneles de ferrocemento. Este artículo presenta la revisión de estudios realizados sobre el comportamiento del panel de ferrocemento bajo cargas estáticas, dinámicas y cíclicas.

Palabras clave- Ferrocemento, carga cíclica, comportamiento de flexión, muro de ferrocemento prefabricado, análisis dinámico, análisis estático.

INTRODUCTION 
Sustainability, Agri, Food and Environmental Research, (ISSN: 0719-3726), 10(X), 2022: http://dx.doi.org/

A large number of civil infrastructures around the world are in a state of serious deterioration today due to carbonation, chloride attack, etc. Moreover many civil structures are no longer considered safe due to increase load specifications inthe design codes or due to overloading or due to under design of existing structures or due to lack of quality control. As a way to keep efficient serviceability, older structures should be repaired or strengthened so that they meet the identical requirements wished for the structures constructed nowadays and in destiny. Ferrocement over the years have gained respect interms of its superior performance and versatility.It can be constructed with a minimum of skilled labour and utilizes readily available materials. There are several applications of Ferrocement which include building industry, irrigation sector, water supply and sanitation areas. Studies indicate that it appears to be an excellent composite in the case of seismic resistant structures.

Ferrocement is a building material composed of a relatively thin layer of concretecovering such reinforcing material as steel wire mesh. It composed of cement, fine aggregate, water and admixtures. Because the building techniques are simple enough to be done by unskilled labour, ferrocement is an attractive construction method in areas where labour costs are low. There is no need for the complicated formwork of reinforced cement concrete (RCC) construction, or for the welding needed for steel construction, everything can be done by hand, and no expensive machinery is needed. The main difference between ferrocement and reinforced concrete is ferrocement is a thin composite made of cement matrix reinforced with closely spaced small diameter wire meshes instead of larger diameter rods and large size aggregates. The thickness of ferrocement generally ranges from $25-50$ $\mathrm{mm}$.

\section{REVIEW OF ANALYSIS OF FERROCEMENT PANELS}

Flexural behaviour of reinforced concrete slabs with ferrocement tension zone cover was observed. Percentage of wire mesh reinforcement in the ferrocement cover layer, thickness of the ferrocement layer and the type of connection between the ferrocement layer and the reinforced concrete slab on the ultimate flexural load, first crack load, crack width and spacing, and the load deflection relationship were examined.This paper proves that reinforced concrete slabs with ferrocement tension zone cover is superior in crack control, stiffness and first crack moment to similar slabs with normal concretecover (Al-Kubaisy and Zamin Jumaat, 2000).

To understand the flexural behavior of ferrocement sandwich panels, the parameters considered in the experimental investigation were the number of wire mesh layers, the skeletal steel, the web mesh reinforcement and the number of webs. Ultimate moment capacities were computed analytically using conventional reinforced concrete theory. 
Sustainability, Agri, Food and Environmental Research, (ISSN: 0719-3726), 10(X), 2022: http://dx.doi.org/

Cracking behavior and failure patterns for all panels were also obtained andcompared. They found that number of ribs and the presence of web mesh reinforcement play an important role in developing full momentcapacities. Increasing the number of wire mesh layers and using skeletal steel in the tension plate improves the ductility in the working range and also the ultimatestrength. The number of wire mesh layers has no significant contribution to stiffness and rigidity in the uncracked stage, but improves stiffness and rigidity in the cracked stage. Increasing the number of ribs beyond the minimum number of ribs required to produce full moment capacity does not improve flexural behaviour much in all three stages (Basunbul et al. 1991).

An experimental investigation of ferrocement panels reinforced with different kinds of mesh to exhibit composite behaviour was conducted. A comparison of results was carried out, both between the two different specimens as well as between experimental and numerical models, in an attempt to reach to some conclusions. The main objective was studying the ultimate load, ultimate deflection and mode of failure of expanded and welded wire mesh specimen. They found that ferrocement concrete specimens reinforced by expanded or welded steel wire mesh exhibit superior ultimate loads under flexuralloadings. Expanded wire mesh contributed to increase load carrying capacity higher than welded wire mesh (Hago et al. 2005).

An investigation of flexural behaviour of ferrocement elements that are used as permanent formwork in concrete members was presented in a paper. Ferrocement panels were tested under flexure and theload deflection results were compared. Theultimate flexural strength of ferrocement panel under twopoint and midpoint loading amounted to $9.42 \mathrm{~N} / \mathrm{mm}^{2}$ and $6.89 \mathrm{~N} / \mathrm{mm}^{2}$, respectively. In all the cases, the failure stateonly depicted cracking and release of load. No delamination or separation of wire mesh was observed. The flexural strength of ferrocement RC composite panelswas slightly higher compared to conventional RC beam. Although the flexural capacity improved, the first crackwas developed near the second ferrocement panel, whichwas placed at the bottom. After the elastic curve and thefirst crack formation, an opening developed in between theferrocement panels. Though the flexural crack progressed and the width of theopening increased, it followed a clear ductile plateau with $10 \%$ increase in ultimate flexural capacity. After a point of time,both conventional RC and Ferrocement RC composite panelsbehaved in the same manner(Kumarasamy et al. 2017).

Results on Ferrocement specimens indicate that the tensile strength depends on both matrix strength and wire mesh ratio. Tensile strain at which plastic stage of stress-strain response commences was found to depend on tensile strain of matrix, tensile strength of matrix and ultimate tensile stress of Ferro cement (Mohammed, 2012).

Effect of using lightweight aggregates on concrete strength -Four samples are constructed which one of them is with sand and the others are with lightweight aggregates 
Sustainability, Agri, Food and Environmental Research, (ISSN: 0719-3726), 10(X), 2022: http://dx.doi.org/

including light weight expanded clay aggregates, pumice and perlite as an alternative to sand. Modeling of these samples with the finite elements method due to the differences in density and modulus of elasticity of concretes is done. The results show that lightweight aggregates can be used in ferrocement applications without any significant difference in their bending strength and also between lightweight ferrocement applications (Aldağ and Eker, 2018).

The ultimate and service behaviour of ferrocement roof slab panels. The parameters of study include: the effect of the percentage of wire mesh reinforcement by volume and the structural shape of the panels on the ultimate flexural strength, first crack load, crack spacing and load-deformation behaviour. Two parameters had been investigated in this research: the structural shape of the slabs and the percentage volume of the reinforcement. Six slabs had been tested, with varying shapes and percentage volume of steel (steel layers). They concluded that slabs with channel sections supported larger ultimate loads and behaved better under service loads than theirflat slabs counterparts. All slabs showed good ductility represented by large deflections giving a horizontal plateau in the load-deflection plot. Ample warning was given prior tofailure. Due to large deflections compared to the small thickness of the panels, it was more appropriate to consider large deflection theory in the analysis (Hago et al. 2005).

The results of testing flat ferrocement panels reinforced with different number of wire mesh layer and variation in panel thickness was observed. The main objective of these experimental tests was to study the effect of using different numbers of wire mesh layers and thickness variation on the flexural strength of flat ferrocement panels and to compare the effect of varying the number of wire mesh layers on the ductility and the ultimate strength of this type of ferrocement structure. Increasing the number of layers of wire mesh from 2 to 4 layers significantly increases the ductility and capability to absorb energy of the panels.Increase in number of mesh layers improves the ductile behaviour of ferrocement slabs. Increasing the thickness also affected the final breaking load for slab panels (Sathe and Rathod, 2020).

In an experimental study investigated the strength and behavior of reinforced concrete (RC) frames with ferrocement infills. The ferrocement infill consists of hexagonal wiremesh with different values of volume fraction of mesh reinforcement. The experimental results indicated that the strength, stiffness, energy dissipation capacity and ductility of frames with ferrocement infill were significantly improved when compared with the bare frame. Infill panels were $50 \mathrm{~mm}$ thick and were centrally placed. Hexagonal wire meshes were used as reinforcement and the volume fraction of hexagonal meshes were varied as $0.20 \%, 0.30 \%$ and $0.40 \%$. The frames were tested under reverse cyclic lateral loading. The addition of infills significantly reduced the displacement and increased the lateral load carrying capacities of the specimens when compared with the bare frame. It may be inferred 
Sustainability, Agri, Food and Environmental Research, (ISSN: 0719-3726), 10(X), 2022: http://dx.doi.org/

that infills make the frame stiffer; also there is a substantial increase in lateral strength. Difference in crack propagation in bare frame and infilled frames can be easily noticed. For bare frames it was mostly concentrated on beam column joints; but for infilled specimens, because of the frame-infill interaction, the applied lateral load got distributed throughout the length of column and hence cracks were observed throughout the column length (Ganesan et al. 2017)

Crack spacing on a large number of ferrocement specimens were observed. It contributes to a clearer understanding that the dominating design criterion for most applications of ferrocement is not the crack width, which cannot be reliably modelled, but the steel stress. The specimen size was $350 \mathrm{~mm}$ × $125 \mathrm{~mm}$ x $30 \mathrm{~mm}$ thick. Six layers of weld mesh were used as reinforcement to give a percentage of reinforcement of about $1.20 \%$. No skeletal steel was used; of ferrocement is not the crack width, which cannot be reliably modelled, but the steel stress. A total of 90 fatigue and 24 static specimens were tested.They reported that there were many fewer cracks in specimens failing by fatigue with a stress level lower than in those failing under static loads. Crack-spacing is one of the most important factors in the control of crack width. The crack-spacing is generally small under cyclic loading, the cracks in ferrocement should have an insignificant influence on the corrosion of steel when the elastic modulus of steel is equal to or higher than $200000 \mathrm{MPa}$ (Xiong, 1994).

The results drawn from cycling loading tests carried out over two types of precast Ferrocement walls (PFWs), in order to determine their strength, hysteretic behavior, ductility, energy dissipation capacity, equivalent viscous damping, and damage limit states. These walls have similar structural systems that differ only in the type of reinforcement. the precast panels of the PFW1 had 4 rebars and eight layers of hexagonal wire mesh that enclosed the rebars, whereas the precast panels of the PFW2 had a layer of welded wire mesh of $\varnothing 5 \mathrm{~mm}$ with opening $150 \mathrm{~mm} \times 150 \mathrm{~mm}$ and eight layers of the hexagonal wire mesh that surrounded the layer of the welded wire mesh. The PFW1 experienced a hysteretic behavior represented by a scant stiffness degradation, cyclic strength deterioration in the last cycles, and moderate pinching effects; whereas the PFW2 experienced a moderate stiffness degradation, severe cyclic strength deterioration in the cycles, as well as severe pinching effects as a result of the opening and closing cracks process. Every ductility level describes the behavior of the wall and the ability of it to maintain high levels of deformation without damage. PFW1 has good energy dissipation capacity when it is subjected to loads beyond its linear range, whereas the PFW2 has an acceptable energy dissipation capacity (Herrera et al., 2020).

Investigation on ferrocement panels reinforced with different kinds of mesh to exhibit composite behaviour was conducted. A comparison of results was carried out, both between the two different specimens as well as between experimental and numerical models, in an 
Sustainability, Agri, Food and Environmental Research, (ISSN: 0719-3726), 10(X), 2022: http://dx.doi.org/

attempt to reach to some conclusions. The main objective was studying the ultimate load, ultimate deflection and mode of failure of expanded and welded wire mesh specimen. They concluded that concrete specimens reinforced by expanded or welded steel wire mesh exhibit superior ultimate loads under flexural loadings Expanded wire mesh contributed to increase load carrying capacity and deflection higher than welded wire mesh. Cracks with greater number and narrower widths were observed for those slabs reinforced with expanded steel wire mesh compared with slabs reinforced with welded steel wire mesh. (Cheah \& Ramli, 2013).

The aim to assess the structural behaviour of ferrocement-reinforced concrete composite slab system with high calcium wood ash (HCWA) high strength mortar used as the compression zone was done. The proposed slab system consisted of conventional reinforced concrete slab topped with a layer of high strength ferrocement composite containing various contents of HCWA by total weight of binder. The main parameters of the study include serviceability moment, ultimate moment capacity, flexural stiffness in serviceability and post cracked conditions, crack width development, crack spacing and failure mode. The strengthening of the compression zone of reinforced concrete slab member using high strength ferrocement composite containing HCWA has a marginal effect on the crack spacing of the composite slab at ultimate failure (Cheah \& Ramli, 2013).

Experimental ferrocement panel result is compared with the conventional panel to observe the flexural behaviour. The test result shows that the ferrocement panel is good in flexural, and that increase in number of wire mesh layers also increase in flexural strength and thus act as an overlay on the pavement. Thus the main aim of this project is to prevent the reflecting crack on the rigid pavement. Based on the experimental test results, the flexural loads at first crack and ultimate loads depends on number of reinforcing mesh layers used in the ferrocement panel. Thus increasing the number of wire mesh layers significantly increases the ductility of the panel (Kumar et al. 2020).

To develop a seismic retrofitting technique to be adopted with locally available materials and an easy retrofitting method suitable for the particular masonry structures, researches were carried out. Brick masonry panels were casted and cyclic loading tests were carried out for two types of walls: walls without applying retrofitting technique and walls retrofitted with Ferrocement belts. Experiments conducted in this study show that Ferrocement belt retrofitted walls significantly increase its inplane strength and ductility capacity. A large increase in ductility, up to $500 \%$, was achieved with Ferro-cement belt applied horizontally and vertically. The specimen with vertical wall opening and diagonal wall opening also give significant increase in ductility up to $330 \%$ and $310 \%$ (De Silva and Abeygunawardana, 2020). 
Sustainability, Agri, Food and Environmental Research, (ISSN: 0719-3726), 10(X), 2022: http://dx.doi.org/

\section{CONCLUSION}

Ferrocement is a type of thin-wall reinforced concrete commonly constructed of hydraulic-cement mortar reinforced with closely spaced layers of continuous and relatively small wire mesh. The mesh may be made of metallic or other suitable materials. Ferrocement has a very high tensile strength-to-weight ratio and superior cracking behavior in comparison to conventional reinforced concrete. Unlike conventional concrete, ferrocement reinforcement can be assembled into its final desired shape and the mortar can be plastered directly in place without the use of a form. Ferro-cement relates to type of thin reinforced concrete consisting of large amount of small diameter wire meshes distributed uniformly throughout the cross section and cement mortar.Ferrocement is preferred for boat construction as it has got high impact resistance. Ferro-cement can be used for the storage of water or other liquid as it is strong, durable \& water-tight. Advantage of Ferro-cement in building food-storage facilities in developing countries is its adaptability to an almost unlimited range of curved shapes and local conditions. Cracking and spalling are some of the major reasons for the deterioration of RCC structures. With time the cracks get deepen and peeling of concrete starts. A good repair improves the function and performance of structures, restore and increase its strength and stiffness, enhances the appearance of the concrete surface, provides water tightness and prevents ingress of the aggressive species to the steel surface durability. Ferrocement can be used for repair purpose of deteriorated RCC structure.

\section{REFERENCES}

Afaf and Abeer. (2019). Experimental and analytical analysis of lightweight ferrocement composite slabs. Engineering research journal. Vol 1, 73-85.

Aldağ, M. C., \& Eker, B. (2018). Application of Finite Element Method in Engineering: a Review. International Refereed Journal of Engineering And Sciences, $0(13), 0-0$.

Al-Kubaisy, M. A., \& Zamin Jumaat, M. (2000). Flexural behaviour of reinforced concrete slabs with ferrocement tension zone cover. Construction and Building Materials, 14(5), 245-252.

Basunbul, I. A., Saleem, M., \& Al-Sulaimani, G. J. (1991). Flexural behavior of ferrocement sandwich panels. Cement and Concrete Composites, 13(1), 21-28.

Cheah, C. B., \&Ramli, M. (2013). Composites: Part B the structural behaviour of HCWA ferrocement - reinforced concrete composite slabs. Composites part b, 51, 68-78.

De Silva, S., \& Abeygunawardana, N. T. (2020). Performance of Ferro-Cement Strengthened Unreinforced Masonry Walls against Reverse Cyclic Loading. Engineer: Journal of the Institution of Engineers, Sri Lanka, 52(4), 11. 
Ganesan, N., Indira, P. V., \& Irshad, P. (2017). Effect of ferrocement infill on the strength and behavior of RCC frames under reverse cyclic loading. Engineering Structures, $151,273-281$.

Hago, A. W., Al-Jabri, K. S., Alnuaimi, A. S., Al-Moqbali, H., \& Al-Kubaisy, M. A. (2005). Ultimate and service behavior of ferrocement roof slab panels. Construction and Building Materials, 19(1), 31-37.

Herrera, J. P., Bedoya-Ruiz, D., \& Hurtado, J. E. (2020). Performance-based seismic assessment of precast ferrocement walls for one and two-storey housing. Engineering Structures, 214(February), 110589.

Kumar, S., Ramachandran, S., \& Barathidason, P. (2020). Flexural Behavior of Ferrocement panel and investigation of Pavement as Ultra-Thin Overlay Flexural Behavior of Ferrocement panel and investigation of Pavement as Ultra-Thin Overlay.

Kumarasamy, S., Sudhahar, A., Babu, D. L. V., \&Venatasubramani, R. (2017). Experimental and numerical analysis of ferrocement RC composite. 69, 915-921.

Mohammed, A. A. (2012). Tensile Stress-Strain Relationship For Ferro cement Structures.vol.20, 27-40.

Sathe, S., \&Rathod, R. (2020). Flexural Behaviour of Ferrocement Slab Panels Using Expanded Metal Mesh. Vol 6, 698-709.

Xiong, G. J. (1994). Crack Space and Crack Width of Weldmesh Ferrocement under Cyclic Loading. Engineering Structures,16, 107-114.

Received: 30th January 2021; Accepted: 10 ${ }^{\text {th }}$ March 2021; First distribution: 01th April 2021 